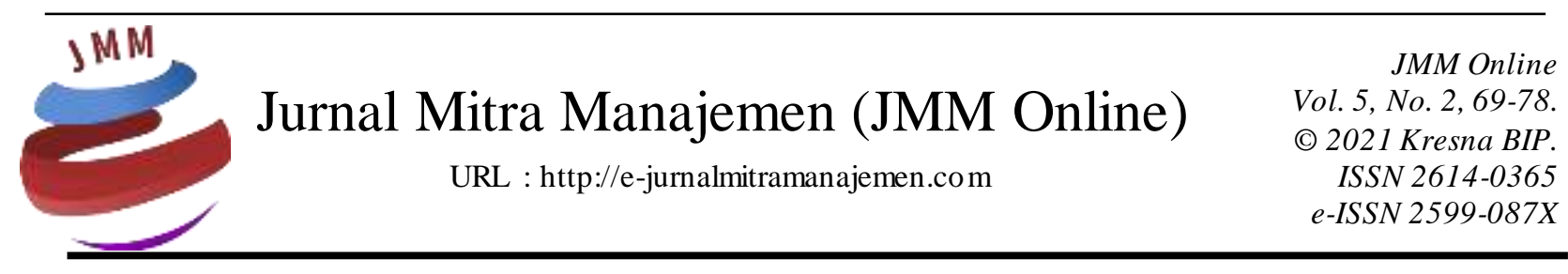

\title{
ANALISIS REAKSI PASAR MODAL TERHADAP PERISTIWA PEMILIHAN UMUM PRESIDEN REPUBLIK INDONESIA PADA TANGGAL 17 APRIL 2019 (STUDI PERISTIWA PADA KELOMPOK SAHAM LQ45 PERIODE APRIL 2019)
}

\author{
Safitri Puji Lestari 1), Imi Yunita ${ }^{2)}$ \\ Universitas Telkom
}

\section{INFORMASI ARTIKEL}

Dikirim : 18 Februari 2021

Revisi pertama : 23 Februari 2021

Diterima : 25 Februari 2021

Tersedia online: 18 Maret 2021

Kata Kunci: Abnormal Return, LQ45, Pemilihan Umum Presiden Republik Indonesia, Studi Peristiwa, Trading Volume Activity

Email : safitripl9@gmail.com

\section{ABSTRAK}

Penelitian ini bertujuan untuk mengetahui perbedaan abnormal return sebelum dan sesudah peristiwa Pemilihan Umum Presiden Republik Indonesia pada tanggal 17 April 2019 pada Bursa Efek Indonesia dan volume perdagangan saham yang dapat diukur menggunakan trading volume activity. Populasi penelitian adalah seluruh perusahaan yang masuk ke perusahaan LQ45 di BEI pada periode Februari - Juli 2019 sebanyak 45 perusahaan. Pengambilan sampel dalam penelitian ini dilakukan dengan metode purposive sampling, artinya jumlah sampel yang diambil adalah sampel yang sesuai dengan kriteria, yaitu sebanyak 45 perusahaan. Penelitian ini menggunakan jenis penelitian studi peristiwa yang digunakan untuk mempelajari reak $s i$ pasar suatu peristiwa yang informasinya dipublikasikan suatu pengumuman. Penelitian ini menggunakan metode kuantitatif, menggunakan data sekunder yang diperoleh melalui teknik pengumpulan data pada dokumen. Untuk menguji hipotesis penelitian ini menggunakan uji Wilcoxon test. Hasil uji hipotesis menggunakan Wilcoxon test pada abnormal return tidak memiliki pengaruh yang signifikan sebelum dan sesudah peristiwa Pemilihan Umum Presiden Republik Indonesia 17 April 2019 dengan nilai signifikansi sebesar 0,835 lebih besar dari 0,05. Sedangakan, hasil uji hipotesis menggunakan Wilcoxon test pada trading volume activity memiliki pengaruh yang signifikan sebelum dan sesudah peristiwa Pemilihan Umum Presiden Republik Indonesia 17 April 2019 dengan nilai signifikansi sebesar 0,003 lebih kecil dari 0,05 . 


\section{PENDAHULUAN \\ Latar Belakang}

Pasar modal di Indonesia telah menunjukkan perkembangannya yang dibuktikan dengan semakin banyaknya emiten yang terdaftar di Bursa Efek Indonesia (BEI). Saat ini pasar modal juga turut berperan dalam langkah perekonomian dan menjadi salah satu faktor pendukung perkembangan perekonomian. Oleh karena itu, Pemerintah Indonesia turut serta mendukung kegiatan pasar modal dengan mengesahkan Undang-Undang Republik Indonesia No. 8 Tahun 1995.

Sebagai suatu instrumen ekonomi, pasar modal tidak lepas dari pengaruh lingkungan, termasuk lingkungan ekonomi dan nonekonomi (Altin, 2015). Pengaruh lingkungan ekonomi dibedakan menjadi dua jenis, yaitu ekonomi mikro dan ekonomi makro. Pengaruh lingkungan ekonomi mikro seperti kinerja perusahaan, perubahan strategi perusahaan, pengumuman laporan keuangan atau dividen perusahaan akan selalu direspons oleh pelaku pasar di pasar modal. Pengaruh lingkungan ekonomi makro, seperti perubahan suku bunga tabungan dan deposito, nilai tukar, inflasi, serta berbagai peraturan pemerintah dan deregulasi ekonomi juga berdampak pada fluktuasi harga dan volume perdagangan di pasar modal.

Pengaruh lingkungan non-ekonomi, walaupun tidak berada langsung di dalam perusahaan, namun tidak dapat dipisahkan dari aktivitas bursa saham. Lingkungan nonekonomi tersebut seperti isu mengenai kepedulian terhadap lingkungan hidup, hak asasi manusia, serta peristiwa-peristiwa politik menjadi faktor utama pemicu fluktuasi harga saham di Bursa Efek Indonesia maupun seluruh dunia (Diniar dan Kiryanto, 2015).

Peristiwa politik sangat erat kaitannya dengan stabilitas perekonomian suatu negara. Di Indonesia peristiwa politik tidak dapat dipisahkan lagi dengan reaksi yang terjadi di pasar modal. Dengan demikian, hal-hal tersebut dapat memperoleh berbagai pendapat dari para investor untuk menanamkan modalnya di Indonesia. Jika peristiwa politik dalam suatu negara dalam keadaan stabil, maka kondisi ekonomi suatu negara akan lebih stabil dan investor akan merespons modal investasi secara positif. Sebaliknya, jika peristiwa politik yang tidak stabil akan mengancam stabilitas ekonomi dan cenderung direspons negatif oleh investor.

Salah satu peristiwa politik yang hendak diuji kandungan informasinya terhadap aktivitas bursa efek di Indonesia adalah peristiwa Pemilihan Umum Presiden Republik Indonesia pada tanggal 17 April 2019. Pengujian kandungan informasi peristiwa pemilihan presiden terhadap aktivitas bursa efek, dimaksudkan untuk melihat reaksi pasar terhadap peristiwa pemilihan RI-1 dan RI-2 diukur dengan abnormal return dan trading volume activity. 
Gambar 1. Indeks Harga Saham LQ45

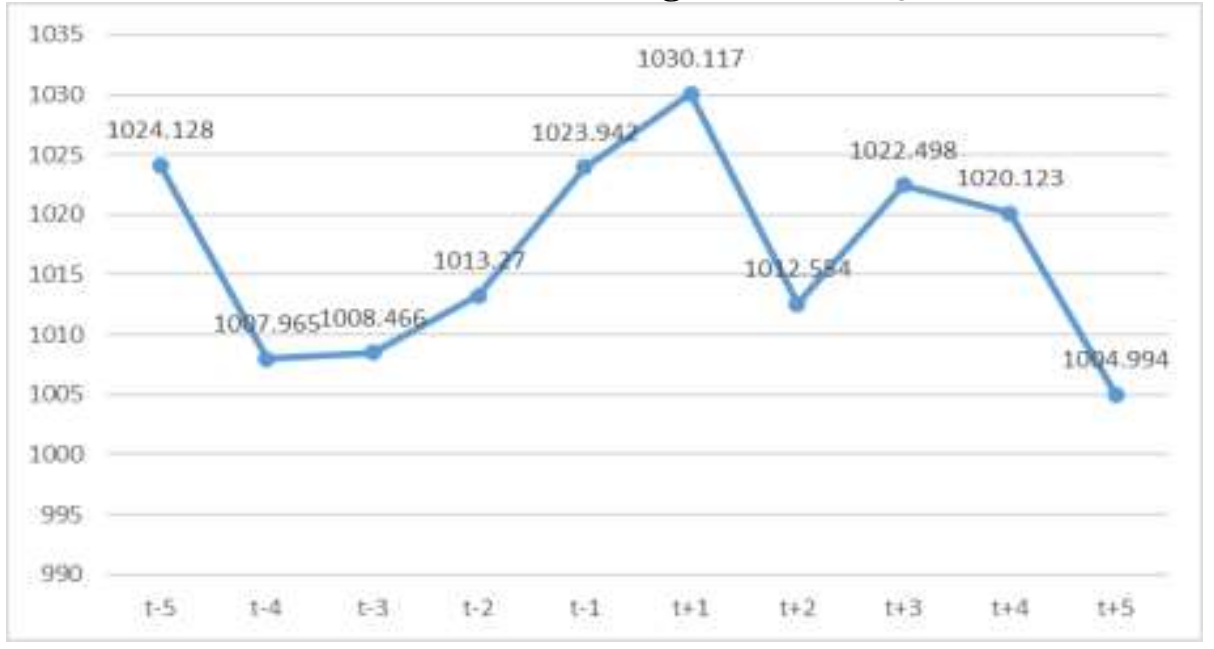

Sumber: www.idx.co.id (diolah), 2021

Sebelum pelaksanaan Pemilu Presiden RI, Indeks LQ45 bergerak secara fluktuatif. Mengalami penurunan nilai terendah pada t-4 pada level 1007,965 dan nilai tertinggi pada satu hari setelah $(\mathrm{t}+1)$ peristiwa pengumuman Pemilu Presiden RI 2019 pada level 1030,117. Dua hari setelah $(t+2)$ peristiwa Pemilu Presiden RI Indeks LQ45 terpantau menurun pada akhir sesi perdagangan hari Senin (22/04/2019). Indeks LQ45 pada satu hari setelah peristiwa terpantau naik 6,176 poin dari level 1023,942 menjadi 1030,117. Namun pada periode selanjutnya t+5 mengalami penurunan yang besar ke level 1004,994.

Pasar yang efisien adalah pasar di mana harga sekuritas yang diperdagangkan telah mencerminkan semua informasi yang tersedia, konsep pasar yang efisien ini lebih ditekankan pada aspek informasi. Pasar efisien dalam bentuk setengah kuat berarti harga pasar saham yang terbentuk sekarang telah mencerminkan informasi historis ditambah dengan semua informasi yang dipublikasikan (Tandelilin, 2017).

Menurut Tandelilin (2017), studi peristiwa atau event study merupakan penelitian yang mengamati dampak dari pengumuman informasi terhadap harga sekuritas. Penelitian event study umumnya berkaitan dengan seberapa cepat informasi yang masuk ke pasar dapat tercermin pada harga saham. Studi peristiwa merupakan bentuk studi untuk menguji efisiensi pasar bentuk setengah kuat (semi strong form).

Menurut Hartono (2017), pengujian kandungan informasi dimaksudkan untuk melihat reaksi dari suatu pengumuman. Jika pengumuman tersebut mengandung informasi maka diharapkan pasar akan bereaksi pada waktu pengumuman tersebut.

Abnormal return menunjukkan kelebihan dari return yang sesungguhnya terjadi terhadap return normal, sedangkan volume perdagangan saham (trading volume activity) merupakan aktivitas atau perilaku riil yang dilakukan investor sebagai reaksi adanya suatu peristiwa. Apabila peristiwa tersebut memiliki kandungan informasi, maka pasar akan bereaksi yang dapat dilihat dari adanya perubahan harga saham dan volume perdagangan saham pada hari-hari di sekitar peristiwa tersebut. Sebaliknya, apabila peristiwa tersebut tidak memiliki kandungan informasi berarti para investor tidak bereaksi terhadap peristiwa yang terjadi (Hartono, 2017:171-173). 
Beberapa penelitian mengenai event study sebelumnya telah dilakukan. Dalam penelitian Sihotang dan Mekel (2015) yang menganalisis apakah pasar modal bereaksi terhadap pemilihan umum presiden tanggal 9 juli 2014 di Indonesia menunjukkan reaksi negatif karena tidak terdapat perbedaan abnormal return periode sebelum dan sesudah Pemilu Presiden 9 Juli 2014 atas saham Perusahaan Konstruksi, Infrastruktur \& Utilitas. Hal ini terbukti dengan hasil abnormal return yang tidak signifikan dengan nilai sig yang lebih besar dari nilai $\alpha$ dan hasil trading volume activity yang signifikan dengan nilai sig yang lebih kecil dari nilai $\alpha$.

Lain halnya dengan penelitian yang dilakukan oleh Hartanto dan Fettry (2019) menganalisis pengaruh debat calon presiden Indonesia 17 Februari 2019 terhadap pasar modal menunjukkan tidak terdapat perbedaan pada abnormal return dan trading volume activity yang signifikan dengan nilai sig lebih besar dari nilai $\alpha$.

Berdasarkan teori yang relevan, maka dapat dirumuskan hipotesis dari penelitian ini adalah sebagai berikut:

H1: Terdapat perbedaan yang signifikan pada abnormal return sebelum dan sesudah peristiwa Pemilihan Umum Presiden Republik Indonesia tahun 2019.

$\mathrm{H} 2$ : Terdapat perbedaan yang signifikan pada trading volume activity sebelum dan sesudah peristiwa Pemilihan Umum Presiden Republik Indonesia tahun 2019.

\section{METODE PENELITIAN}

Penelitian ini menggunakan pendekatan event study yaitu studi peristiwa yang menyelidiki respon pasar terhadap kandungan informasi suatu pengumuman atau publikasi suatu peristiwa tertentu, dengan melihat reaksi pasar terhadap suatu peristiwa yaitu pemilihan presiden Republik Indonesia pada tanggal 17 April 2019, periode penelitian dari 10 April 2019 sampai dengan 25 April 2019.

Sampel dalam penelitian ini adalah populasi seluruh perusahaan yang terdaftar dalam Indeks LQ45 di Bursa Efek Indonesia tahun 2019. Teknik pengambilan sampel dalam penelitian ini adalah purposive sampling dengan hasil sebanyak 45 saham yang terdaftar pada Indeks LQ45 periode Februari-Juli 2019. Data yang peneliti kumpulkan adalah harga saham harian yaitu harga penutupan (closing price) perdagangan 5 hari sebelum peristiwa dan 5 hari esudah peristiwa sekitar periode penelitian. Data yang digunakan peneliti berasal dari www.idx.com.

Terdapat langkah-langkah perhitungan sebelum tahap pengolahan data dan analisis data. Langkah-langkah perhitungan dalam penelitian ini adalah sebagai berikut:

1. Menghitung actual return. Penghitungan actual return membutuhkan data harga saham atau harga penutupan masing-masing perusahaan selama periode penelitian. Dengan rumus:

$$
\begin{array}{ll}
R_{i, t}=\frac{\left(P_{i, t}-P_{i, t-1}\right)}{P_{i, t-1}} & \text { return sesungguhnya yang terjadi untuk sekuritas i periode peristiwa } \mathrm{t} \\
R_{i, t} & =\text { harga saham harian sekuritas i pada periode ke- } \mathrm{t} \\
P_{i, t} & =\text { harga saham harian sekuritas i pada periode sehari sebelum periode } \mathrm{t} \\
P_{i, t-1} &
\end{array}
$$


2. Menghitung expected return. Perhitungan expected return dalam penelitian ini menggunakan model market adjusted. Untuk menghitung return yang diharapkan, diperlukan data indeks saham harian. Dengan rumus:

$E\left[R_{i, t}\right]=R_{\text {Mit }}$

$R_{\text {Mit }}=$ return pasar dari sekuritas i periode peristiwa $\mathrm{t}$

3. Menghitung abnormal return. Metode penghitungan abnormal return pada penelitian ini adalah market-adjusted model, metode ini digunakan untuk menghitung abnormal return dengan cara menghilangkan pengaruh pasar terhadap return harian sekuritas sehingga dalam teknik ini estimasi return sekuritas sama dengan pengembalian indeks saham saat ini. Perhitungan abnormal return mensyaratkan aactual return dan expected return dari sekuritas pada hari yang sama harus sama dengan return indeks pasar. Dengan rumus:

$A R_{i, t}=R_{i, t}-R_{M_{t} t}$

$A R_{i, t} \quad=$ abnormal return sekuritas i pada periode peristiwa $\mathrm{t}$

$R_{i, t} \quad=$ actual return sekuritas i pada periode peristiwa $\mathrm{t}$

$R_{M, t} \quad=$ return pasar dari sekuritas i periode peristiwa $\mathrm{t}$

4. Menghitung trading volume activity. Aktivitas trading volume activity merupakan perbandingan antara jumlah saham yang diperdagangkan pada suatu waktu tertentu dengan jumlah saham yang beredar pada suatu waktu tertentu (Husnan, 2009: 283). Perhitungan ini bertujuan untuk melihat volume penjualan saham pada hari tersebut. Dengan rumus:

$T V A_{i, t}=\frac{\text { Esaham perwsahaani yang diperdagangkan padawaktut }}{\text { Esaham perusahaan i yang beredarpada waktut }}$

$T V A_{i, t}=$ trading volume activity sekuritas I pada waktu ke-t

5. Setelah melakukan penghitungan data, langkah selanjutnya adalah pengolahan data dan analisis data. Tingkat signifikansi $(\alpha)$ yang digunakan dalam penelitian adalah $5 \% \quad(\alpha=0,05)$ atau dengan tingkat kepercayaan 95\%. Selanjutnya adalah uji normalitas data, uji normalitas dalam penelitian ini menggunakan uji statistik Shapiro-Wilk, dengan pengambilan keputusan ini jika Asymp.sig> nilai signifikansi 0,05 maka data dapat disimpulkan berdistribusi normal. Sedangkan jika Asymp.sig <nilai signifikansi 0,05 maka dapat disimpulkan bahwa data tidak berdistribusi normal.

Selanjutnya adalah tahap uji statistik, jika data berdistribusi normal maka uji statistik yang digunakan adalah uji statistik parametrik yaitu uji paired sample t-test. Sedangkan jika data tidak berdistribusi normal maka uji statistik yang digunakan adalah non parametrik yaitu uji wilcoxon.

\section{HASIL PENELITIAN DAN PEMBAHASAN}

Jangka waktu penelitian adalah 5 hari sebelum acara pengumuman dan 5 hari setelah pengumuman dengan pengumuman Pemilu Presiden Republik Indonesia yaitu pada tanggal 17 April 2019. Dengan demikian, jangka waktu penelitian ini adalah 10 April 2019 - 25 April 2019 (tidak termasuk perdagangan saham hari libur).

Sampel dalam penelitian ini adalah perusahaan yang termasuk dalam kelompok saham LQ45. Sampel dalam penelitian ini menggunakan teknik purposive sampling dengan kriteria perusahaan yang termasuk pada indeks LQ45 periode 
Februari-Juli 2019, aktif memperjualkan saham, dan tidak melakukan aksi korporasi selama periode penelitian. Berdasarkan kriteria tersebut maka jumlah sampel perusahaan yang diperoleh adalah 45 perusahaan yang memenuhi kriteria sampel dalam penelitian ini.

Berikut ini adalah rata-rata abnormal return dan trading volume activity 45 perusahaan saham indeks LQ45.

Tabel 1. Rata-Rata Abnormal return Indeks LQ45

\begin{tabular}{|l|l|c|c|}
\hline \multirow{2}{*}{ No } & \multicolumn{1}{|c|}{ Nama Perusahaan } & \multicolumn{2}{c|}{ Abnormal Return } \\
\cline { 2 - 4 } & & Sebelum & Sesudah \\
\hline 1 & Adhi Karya (Persero) Tbk. & 0.010483803 & -0.00219998 \\
\hline 2 & Adaro Energy Tbk. & 0.001680644 & 0.001161917 \\
\hline 3 & AKR Corporindo Tbk. & -0.004384861 & 0.002664195 \\
\hline 4 & Aneka Tambang Tbk. & -0.000998754 & -0.002004554 \\
\hline 5 & Astra International Tbk. & 0.001466477 & -0.001649202 \\
\hline 6 & Bank Central Asia Tbk. & -0.001734837 & 0.00700854 \\
\hline 7 & Bank Negara Indonesia (Persero) Tbk. & 0.000603437 & 0.001384358 \\
\hline 8 & Bank Rakyat Indonesia (Persero) Tbk. & 0.001467668 & 0.00298895 \\
\hline 9 & Bank Tabungan Negara (Persero) Tbk. & 0.018390159 & -0.00670251 \\
\hline 10 & Bank Mandiri (Persero) Tbk. & -0.000363726 & 0.00406369 \\
\hline 11 & Barito Pacific Tbk. & 0.016935471 & 0.006873369 \\
\hline 12 & Bumi Serpong Damai Tbk. & -0.008007121 & 0.0015442 \\
\hline 13 & Charoen Pokphand Indonesia Tbk & -0.012542189 & -0.029846595 \\
\hline 14 & Elnusa Tbk. & 0.003276922 & 0.01378536 \\
\hline 15 & Erajaya Swasembada Tbk. & -0.018891331 & 0.011055519 \\
\hline 16 & XL Axiata Tbk. & 0.01715051 & 0.010848782 \\
\hline 17 & Gudang Garam Tbk. & 0.008021816 & -0.002070653 \\
\hline 18 & H.M. Sampoerna Tbk. & 0.007319522 & -0.015387978 \\
\hline 19 & Indofood CBP Sukses Makmur Tbk. & -0.004156451 & 0.003405865 \\
\hline 20 & Vale Indonesia Tbk. & -0.003341507 & -0.014166178 \\
\hline 21 & Indofood Sukses Makmur Tbk. & -0.002630925 & -0.002839585 \\
\hline 22 & Indika Energy Tbk. & -0.005510365 & 0.003727322 \\
\hline 23 & Indah Kiat Pulp \& Paper Tbk. & -0.019256674 & -0.014449788 \\
\hline 24 & Indocement Tunggal Prakarsa Tbk. & -0.007187304 & -0.000776276 \\
\hline 25 & Indo Tambangraya Megah Tbk. & 0.003169087 & 0.005160861 \\
\hline 26 & Jasa Marga (Persero) Tbk. & -0.002283074 & 0.0017686 \\
\hline 27 & Kalbe Farma Tbk. & -0.005818956 & $7.38612 E-05$ \\
\hline 28 & Matahari Department Store Tbk. & -0.014779004 & 0.02786254 \\
\hline 29 & Medco Energi Internasional Tbk. & -0.002183104 & 0.015316869 \\
\hline 30 & Media Nusantara Citra Tbk. & 0.010158514 & 0.026767306 \\
\hline 31 & Perusahaan Gas Negara (Persero) Tbk. & 0.006258822 & 0.001959848 \\
\hline 32 & Bukit Asam Tbk. & -0.004366479 & 0.006006283 \\
\hline 33 & PP (Persero) Tbk. & 0.015140659 & -0.000432013 \\
\hline 34 & Pakuwon Jati Tbk. & -0.007577713 & 0.006457526 \\
\hline 35 & Surya Citra Media Tbk. & 0.006741841 & -0.000613038 \\
\hline & & \\
\hline
\end{tabular}




\begin{tabular}{|c|l|c|c|}
\hline 36 & Semen Indonesia (Persero) Tbk. & -0.008423772 & 0.004186579 \\
\hline 37 & Sri Rejeki Isman Tbk. & -0.002305846 & 0.003356785 \\
\hline 38 & Pabrik Kertas Tjiwi Kimia Tbk. & -0.000761144 & -0.01627114 \\
\hline 39 & Telekomunikasi Indonesia (Persero) Tbk. & -0.004968538 & 0.001344044 \\
\hline 40 & Chandra Asri Petrochemical Tbk. & $7.26186 \mathrm{E}-05$ & -0.00232786 \\
\hline 41 & United Tractors Tbk. & 0.000196032 & 0.012803446 \\
\hline 42 & Unilever Indonesia Tbk. & 0.001794739 & -0.008859062 \\
\hline 43 & Wijaya Karya (Persero) Tbk. & 0.011146632 & 0.001970516 \\
\hline 44 & Waskita Beton Precast Tbk. & 0.014410078 & -0.001145999 \\
\hline 45 & Waskita Karya (Persero) Tbk. & 0.012936297 & 0.000714191 \\
\hline
\end{tabular}

Sumber : Hasil Penelitian, diolah (2019)

Hasil uji normalitas data rata-rata abnormal return dan trading volume activity adalah sebagai berikut.

Tabel 3. Uji Normalitas Data Abnormal Return

\begin{tabular}{|c|c|c|c|c|}
\hline \multirow{2}{*}{\multicolumn{2}{|c|}{ Peristiwa }} & \multicolumn{3}{|c|}{ Shapiro-Wilk } \\
\hline & & Statistic & $\mathrm{df}$ & Sig. \\
\hline \multirow[t]{2}{*}{ Hasi } & Abnormal return Sebelum & .972 & 45 & .350 \\
\hline & Abnormal return Sesudah & .923 & 45 & .005 \\
\hline
\end{tabular}

Tabel 3 di atas menunjukkan data rata-rata abnormal return. Probabilitas signifikansi saham LQ45 sebelum peristiwa tersebut adalah 0,350 yang berarti lebih besar dari $0,05\left(\mathrm{H}_{0}\right.$ diterima) atau data berdistribusi normal. Probabilitas signifikansi sesudah peristiwa adalah 0,005 yang berarti lebih kecil dari $0,05\left(\mathrm{H}_{0}\right.$ ditolak) atau data tidak berdistribusi normal. Hal ini menunjukkan bahwa data abnormal return saham LQ45 tidak berdistribusi normal.

Tabel 4. Uji Normalitas Data Trading volume activity

\begin{tabular}{lllll}
\hline \multirow{2}{*}{ Peristiwa } & \multicolumn{3}{l}{ Shapiro-Wilk } \\
\cline { 2 - 5 } Hasil & Trading volume activity Sebelum & .722 & df & Sig. \\
\cline { 2 - 5 } & Trading volume activity Sesudah & .660 & 45 & .000 \\
\hline
\end{tabular}

Sumber : Hasil Penelitian, diolah (2019)

Tabel 4 di atas menunjukkan data rata-rata trading volume activity. Probabilitas signifikansi saham LQ45 sebelum peristiwa tersebut adalah 0,000 yang berarti lebih kecil dari 0,05 ( $\mathrm{H}_{0}$ ditolak) atau data tidak berdistribusi normal. Probabilitas signifikansi sesudah peristiwa adalah 0,000 yang berarti lebih kecil dari $0,05 \quad\left(\mathrm{H}_{0}\right.$ ditolak) atau data tidak berdistribusi normal. Hal ini menunjukkan bahwa data trading volume activity saham LQ45 tidak berdistribusi normal.

Tabel 5. Hasil Uji Hipotesis Wilcoxon Test Rata-Rata Abnormal return Saham

\begin{tabular}{|l|l|}
\hline & AR Sesudah - AR Sebelum \\
\hline Z & $-.209^{\mathrm{b}}$ \\
\hline Asymp. Sig. (2-tailed) & .835 \\
\hline
\end{tabular}

Sumber : Hasil Penelitian, diolah (2019)

Tabel 5 di atas menunjukkan ouput hasil uji hipotesis menggunakan Wilcoxon test pada rata-rata abnormal return saham LQ45 sebelum dan sesudah peristiwa 
Pemilihan Umum Presiden Republik Indonesia tahun 2019. Pada waktu sebelum dan sesudah peristiwa terjadi, nilai z hitung sebesar -0,209 dengan nilai Asymp. Sig. 0,835 atau lebih besar dari 0,05 . Artinya, $\mathrm{H}_{0}$ diterima atau tidak terdapat perbedaan yang signifikan pada abnormal return sebelum dan sesudah peristiwa Pemilihan Umum Presiden Republik Indonesia tahun 2019.

Hasil tersebut didukung oleh penelitian yang dilakukan oleh Hartanto dan Fettry (2019) dimana hasil penelitian menunjukkan tidak terdapat perbedaan abnormal return sebelum dan sesudah debat calon presiden Indoensia 17 Februari 2019. Hasil penelitian sebelumnya yang dilakukan oleh Sihotang dan Mekel (2015) dimana hasil penelitian menunjukkan reaksi negatif karena tidak terdapat perbedaan abnormal return sebelum dan sesudah Pemilu Presiden RI 9 Juli 2014 atas saham Perusahaan Konstruksi, Infrastruktur \& Utilitas. Hasil penelitian yang dilakukan oleh Luhur (2010) tidak terdapat perbedaan abnormal return sebelum dan sesudah peristiwa pemilu presiden 8 Juli 2009 pada saham LQ45 yang terdaftar di BEI.

Dari penjelasan di atas dapat disimpulkan Pemilu Presiden Republik Indonesia tahun 2009, 2014, dan 2019 tidak memiliki perbedaan abnormal return sebelum dan sesudah peristiwa. Dengan demikian, investor Indonesia percaya dengan pemimpin

Indonesia yang memimpin pada masanya saat itu, baik Susilo Bambang Yudhoyono pada tahun 2009-2014 maupun Joko Widodo pada tahun 2014-sekarang. Hal ini menunjukkan bahwa investor Indonesia sudah rasional dalam berinvestasi.

Para investor menganalisis lebih lanjut informasi yang benar-benar relevan terkait dengan keputusan investasi. Informasi yang relevan dapat didapatkan tidak hanya dari anlisis teknikal yaitu berdasarkan pada data pasar historis seperti informasi harga dan volume, tetapi juga analisis fundamental meliputi analisis ekonomi, analisis industri, dan analisis perusahaan. Sehingga, dalam peristiwa politik pemilu presiden tidak mempengaruhi pengambilan keputusan investasi, tetapi kinerja perusahaan menjadi acuan dalam keputusan berinvestasi. Artinya, pasar modal di Indonesia pada April 2019 dapat digolongkan sebagai pasar efisien setengah kuat atau disebut juga semi strong form.

Tabel 6. Hasil Uji Hipotesis Wilcoxon Test Rata-Rata Rading Volume Activity Saham

\begin{tabular}{|l|l|}
\hline & TVA Sesudah - TVA Sebelum \\
\hline $\mathrm{Z}$ & $-2.997^{\mathrm{b}}$ \\
\hline Asymp. Sig. (2-tailed) & .003 \\
\hline
\end{tabular}

Sumber : Hasil Penelitian, diolah (2019)

Tabel 6 di atas menunjukkan ouput hasil uji hipotesis menggunakan Wilcoxon test pada rata-rata trading volume activity saham LQ45 sebelum dan sesudah peristiwa Pemilihan Umum Presiden Republik Indonesia tahun 2019. Pada waktu sebelum dan sesudah peristiwa terjadi, nilai z hitung sebesar -2,997 dengan nilai Asymp. Sig. 0,003 atau lebih kecil dari 0,05 . Artinya, $\mathrm{H}_{0}$ ditolak $\left(\mathrm{H}_{\mathrm{a}}\right.$ diterima) atau terdapat perbedaan yang signifikan pada trading volume activity sebelum dan sesudah peristiwa Pemilihan Umum Presiden Republik Indonesia tahun 2019.

Hasil tersebut didukung oleh penelitian sebelumnya yang dilakukan oleh Sihotang dan Mekel (2015) dimana hasil penelitian menunjukkan reaksi positif karena terdapat perbedaan trading volume activity sebelum dan sesudah Pemilu Presiden RI 9 
Juli 2014 atas saham Perusahaan Konstruksi, Infrastruktur \& Utilitas. Namun, untuk penelitian yang dilakukan oleh Hartanto dan Fettry (2019) menunjukkan hasil tidak terdapat perbedaan yang signifikan pada trading volume activity sebelum dan sesudah peristiwa debat calon presiden Indoensia 17 Februari 2019. Penelitian yang dilakukan oleh Luhur (2010) menunjukkan hasil tidak terdapat perbedaan trading volume activity secara signifikan sebelum dan sesudah peristiwa pemilu presiden 8 Juli 2019.

Hal ini menandakan bahwa investor telah menganalisis bagaimana keberlangsungan proses Pemilihan Umum Presiden Republik Indonesia pada tanggal 17 April 2019. Hal ini menunjukkan bahwa walaupun trading volume activity meningkat dan biasanya investor bersedia jual dan/atau beli dengan harga dan jumlah yang diinginkan, namun tidaklah selalu mendapatkan keuntungan sesuai dengan yang diharapkan.

\section{KESIMPULAN DAN SARAN \\ Kesimpulan}

Berdasarkan pengujian dan pembahasan yang telah diuraikan, maka kesimpulan dari hasil abnormal return dan trading volume activity saham LQ45 periode April 2019 terhadap Pemilihan Umum Presiden Republik Indonesia 17 April 2019 sebagai berikut:

1. Dalam pengujian dan pembahasan abnormal return saham LQ45 periode April 2019 terhadap Pemilihan Umum Presiden Republik Indonesia 17 April 2019 hasil Wilcoxon test tidak memiliki pengaruh signifikan terhadap harga saham LQ45 sebelum dan sesudah peristiwa.

2. Dalam pengujian dan pembahasan trading volume activity saham LQ45 periode April 2019 terhadap Pemilihan Umum Presiden Republik Indonesia 17 April 2019 hasil Wilcoxon test memiliki pengaruh signifikan terhadap harga saham LQ45 sebelum dan sesudah peristiwa.

\section{Saran}

Saran bagi penelitian selanjutnya, diharapkan untuk melakukan penelitian menggunakan peristiwa-peristiwa lain yang diperkirakan berdampak pada pasar modal Indonesia. Menggunakan periode yang berbeda dalam periode pengamatan untuk mengetahui periode mana yang lebih efektif. Model yang digunakan dalam penelitian ini untuk menemukan expected retun adalah market-adjusted model. Diharapkan pada penelitian selanjutnya untuk menggunakan model lain sehingga dapat diketahui model mana yang sesuai untuk peristiwa dalam pengujian pasar modal. Objek penelitian menggunakan Indeks Saham LQ45, diharapkan penelitian selanjutnya menggunakan objek penelitian yang berbeda.

Disarankan bagi investor jangka panjang dan jangka pendek lebih memperhatikan berbagai informasi dari berbagai aspek informasi internal perusahaan seperti laporan keuangan dan informasi eksternal perusahaan seperti Pemilu Presiden RI. Sehingga dapat meminimalkan kerugian. Hal ini termasuk memperhatikan berbagai peristiwa ekonomi dan nonekonomi yang diperkirakan akan mempengaruhi naik turunnya harga saham sebelum berinvestasi. 


\section{DAFTAR PUSTAKA}

Altin, H. 2015. Efficient Market Hypothesis, Abnormal return and Election Periods. European Scientific Journal, 169-178.

Bursa Efek Indonesia. 2018. Ikhtisar. Dipetik Maret 12, 2020, dari idx.co.id: https://www.idx.co.id/tentang-bei/ikhtisar/

Bursa Efek Indonesia. 2020. Indeks Saham. Dipetik Maret 12, 2020, dari idx.co.id: https://www.idx.co.id/data-pasar/data-saham/indeks-saham/

Diniar, A. H., \& Kiryanto. 2015. Analisis Dampak Pemilu Presiden Jokowi terhadap Return Saham (studi Kasus Saham LQ45 di Bursa Efek Indonesia). Jurnal Akuntansi Indonesia, 97-108.

Hartanto, A. P., \& Fettry, S. 2019. Pengaruh Debat Calon Presiden Indonesia 17 Februari 2019 Terhadap Abnormal return dan Trading volume activity (Studi Kasus pada Pperusahaan Indeks LQ45 di Bursa Efek Insonesia). Jurnal Akuntansi Bisnis \& Ekonomi.

Hartono, J. 2016. Teori Portofolio dan Analisis Investasi (10 ed.). Yogyakarta: BPFE Yogyakarta.

Husnan, S. 2005. Dasar-Dasar Teori Portofolio dan Analisis Sekuritas. Edisi. Keempat. Yogyakarta: UPP AMP YKPN.

Luhur, S. 2010. Reaksi Psar Modal Indonesia Seputar Pemilihan Umum 8 Juli 2009 pada Saham LQ-45. Jurnal Keuangan dan Perbankan.

Republik Indonesia. 1995. Undang-Undang Nomor 8 Tahun 1995 tentang Pasar Modal. Jakarta: Sekretariat Negara.

Sihotang, E. M., \& Mekel, P. A. 2015. Reaksi Pasar Modal Terhadap Pemilihan Umum Presiden Tanggal 9 Juli 2014 di Indonesia (Studi di Perusahaan Konstruksi, Infrastruktur, dan Utilitas pada BEI, Jakarta). Jurnal EMBA.

Tandelilin, E. 2017. Pasar Modal: Manajemen Potofolio \& Investasi. Yogyakarta: Kanisius. 